\title{
20. SITE SURVEYS IN THE MARIANA AREA (SCAN IV)
}

\author{
D. Karig, Scripps Institution of Oceanography, La Jolla, California
}

During the fourth and fifth legs of Scan Expedition, drill Sites 53 and 60 were surveyed and Site 59 was traversed. In addition to the drill site surveys, several other areas across the Mariana Arc System were investigated in some detail, guided by reconnaissance work aboard the $R / V$ Argo from the previous year. These data, together with previously published work (Tracey et al., 1964; Cloud et al., 1956; and Murauchi et al., 1968), make it possible to outline the structural framework in which the drill sites lie.

The remarkable similarities in the occurrence and relative positions of a wide range of structural features in western Pacific arc systems strongly suggest a common mechanism of origin. The area in which crustal deformation related to island arc tectonism is occurring, more extensive and complex than generally recognized, is defined as the active island arc system; this includes not only the trench and volcanic chain, but also the deep basin and submarine ridge on the concave side of the active volcanoes (Figure 1).

In Figure 2, the tectonic units of the Mariana area and the geographical names used in this paper are shown. Basically, the active arc system includes a trench and, to the rear, two ridges separated by a tectonically active basin. Both ridges, the frontal arc on the east and the third arc to the west, have asymmetric crosssections, but in opposite directions (Figure 1). Steep scarps face the active inter-arc basin and gentle flanks, covered with sediment aprons, face away from that basin. A marked paucity of sediment within the interarc basin, the strongly faulted basin margins, and the relationship of the basin geology with that of the bounding ridges were the primary evidence cited for the extensional origin of the inter-arc basin (Karig, 1969,
1970). The third arc appears to have been contiguous with the frontal arc before the inter-arc basin opened, and has since subsided at least a kilometer (Karig, 1970, in preparation).

Behind these active units lie other basins and submarine ridges of the Philippine Sea in which island arc related tectonism does not now appear to be occurring. These ridges are thought to be remnants of early to midTertiary frontal arcs rifted away from and left behind the present frontal arc by creation of oceanic crust in the basins. Such a mechanism resulted in the migration of the active arcs and trenches away from the Asian and Australian areas.

One of the predictions drawn from this model is that the age of the basins behind trenches should increase with increasing distance from the active system. Deep Sea Drilling was capable of partially testing this proposition.

Site 53 in the Parece Vela Basin was the first of the Mariana sites investigated. Centered near $18^{\circ} \mathrm{N}, 141^{\circ} \mathrm{E}$, the survey area was located on the toe of the sediment apron extending westward from the West Mariana Ridge (third arc, Figure 2) in water depths averaging 4700 meters. The sea floor is generally flat, but it is marked by north-north-east trending ridges and troughs, several of which are closed depressions (Figure 3). A piston core (Scan 39P) near the drill site (Figure 3) recovered 251 centimeters of red-brown nonfossiliferous clay, which contained neither zeolites nor more than a trace of volcanic glass. However, the 85centimeter trigger weight core (Scan 39PG) showed a sharp upward increase in volcanic glass between 85 and

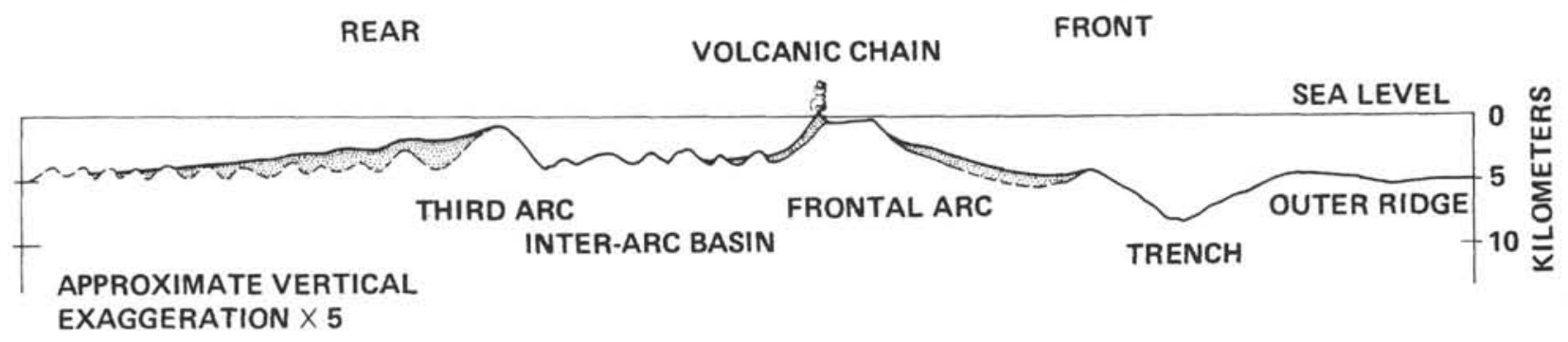

Figure 1. Idealized cross-section of a western Pacific island arc system (modified after Karig, 1970). 
50 centimeters depth and abundant Ethmodiscus. fragments and Quaternary Radiolaria at 10 centimeters. The absence of this interval in the piston core and an external core penetration of almost 400 centimeters indicate that the piston core failed to sample the uppermost section. If the initiation of the present phase of volcanism in the Mariana Arc System in the late Pliocene (Karig, in preparation) is represented by the increase of glass content in the gravity core, the rate of Quaternary sedimentation in the site area is very low, even with recognition of omission and shortening of the cores. Bottom photographs (Scan 39C) near the core location (Figure 4) showed a smooth bottom approximately 30 per cent covered with dark fragments several centimeters across. These are more likely to be manganese nodules than "floated" pumice because of the presence of manganese micronodules near the ocre surface and because of the suspected low rate of deposition in the area.

The $3.5 \mathrm{kh}$ profiles define a surficial 15 - to 20 -meter thick sedimentary unit which has the blanket character of a pelagic or himi-pelagic deposit (Figure 5). This unit, at least the upper section, is probably composed of red clay similar to that cored. The thickness of the pelagic deposit is very constant, increasing only slightly in some troughs. Eastward from the site area the unit thickens gradually as the bottom rises, reflecting an increasing rate of both volcanically derived and calcareous deposition (Karig, in preparation). The series of strong reflectors marking the base of the pelagic unit appears to be a conformable transition to the distinctively different sediments below. This underlying section, which has the geometric characteristics of laterally transported sediments, is several hundred meters thick at the western edge of the survey area and thickens rapidly eastward to more than a kilometer, forming a sizable sediment apron along the west side of the West Mariana Ridge (Figure 5). Similar aprons were identified behind the third arcs of the Tonga-Kermadec and New Hebrides arc systems and evidence was given indicating sediment sources toward the third arcs (Karig, 1970). The apron sediments are generally acoustically reflective, but individual horizons cannot be followed for great distances. A prominent reflecting horizon near the base of the section appears to be traceable throughout the survey area, and illustrates the ponding of the older sediments in basement troughs.

The acoustic basement beneath the apron sediments consists of north-north-east trending ridges and troughs which appear to be titled fault blocks. Above the scarps bounding the basement ridges, the sediments are faulted or sharply folded. Upward decreasing displacement along many of these structures, and the ridges and troughs in the apron surface suggest that faulting continued until near the end of the apron formation. It blanket to faulting on the profiler records, but the thickening of this blanket in the surficial troughs sug. gests that these sediments accumulated after faulting ceased.

In addition to these geologic data, heat flow measurements and continuous magnetic profiles were obtained during the survey of Site 53. The magnetic field in the area has perturbations of less than 50 gammas. That these are in the range of the diurnal variations was indicated by the discrepancies in magnetic field intensities on crossing tracks. Two heat flow stations in the Parece Vela Basin (Figure 3) gave preliminary, but relatively high values of 1.89 (Scan 37QV) and 2.13 (Scan 38QV) $10^{-6} \mathrm{cal} / \mathrm{cm}^{2} / \mathrm{sec}$ (T. Watanabe, personal communication).

Eastward from Site 53 the increase in both the thickness of the sediment apron and the reflectivity of the apron sediments prevented the profiler system from recording basement (Figure 5). The apron at $18^{\circ} \mathrm{N}$ is over 250 kilometers wide, and shallows eastward to a depth of 3400 meters; it is bounded by the sharply rising basement core of the third arc. This basement core appears to have steep scarps on both flanks, but the superposition of the sediment apron on the west flank causes the arc to have a morphologically asymmetrical cross-section. Thirty to forty kilometers west of the linear third arc basement ridge is a line of seamounts which are very likely older analogs of the active andesite centers along the frontal arc.

The eastern flank of the third arc is a very steep, 3500 meter high scarp, which marks the sharp transition into the tectonically active inter-arc basin (Mariana Trough). The floor of this basin is extremely rough, with only a thin and irregular sediment cover (Figures 5 and 6). Almost all morphologic characteristics of this basement are identical to those of the basement in the Parece Vela Basin. The similar basement and overlying volcanically derived sediment apron, built from eastern sources, is one of the stronger indications of the common origin of the Mariana Trough and Parece Vela Basin. A detailed survey in the center of the basin (Karig, in preparation) demonstrates that the 1500-meter basement relief reflects northerly trending fault blocks, covered by and probably composed of basalt. During the survey, fresh basalt was dredged from three localities along the axis of the basin.

The sediment cover of the Mariana Trough consists of small ponds of volcanic mud in the basement troughs and an apron of coarser volcanic clastics flanking the active andesite volcanoes at the eastern edge of the basin (Karig, in preparation). Sediments dredged from the basement contact and from the scarps bounding the basin are no older than very late Pliocene in age. Thus, the more than 500 meters of material deposited in the 


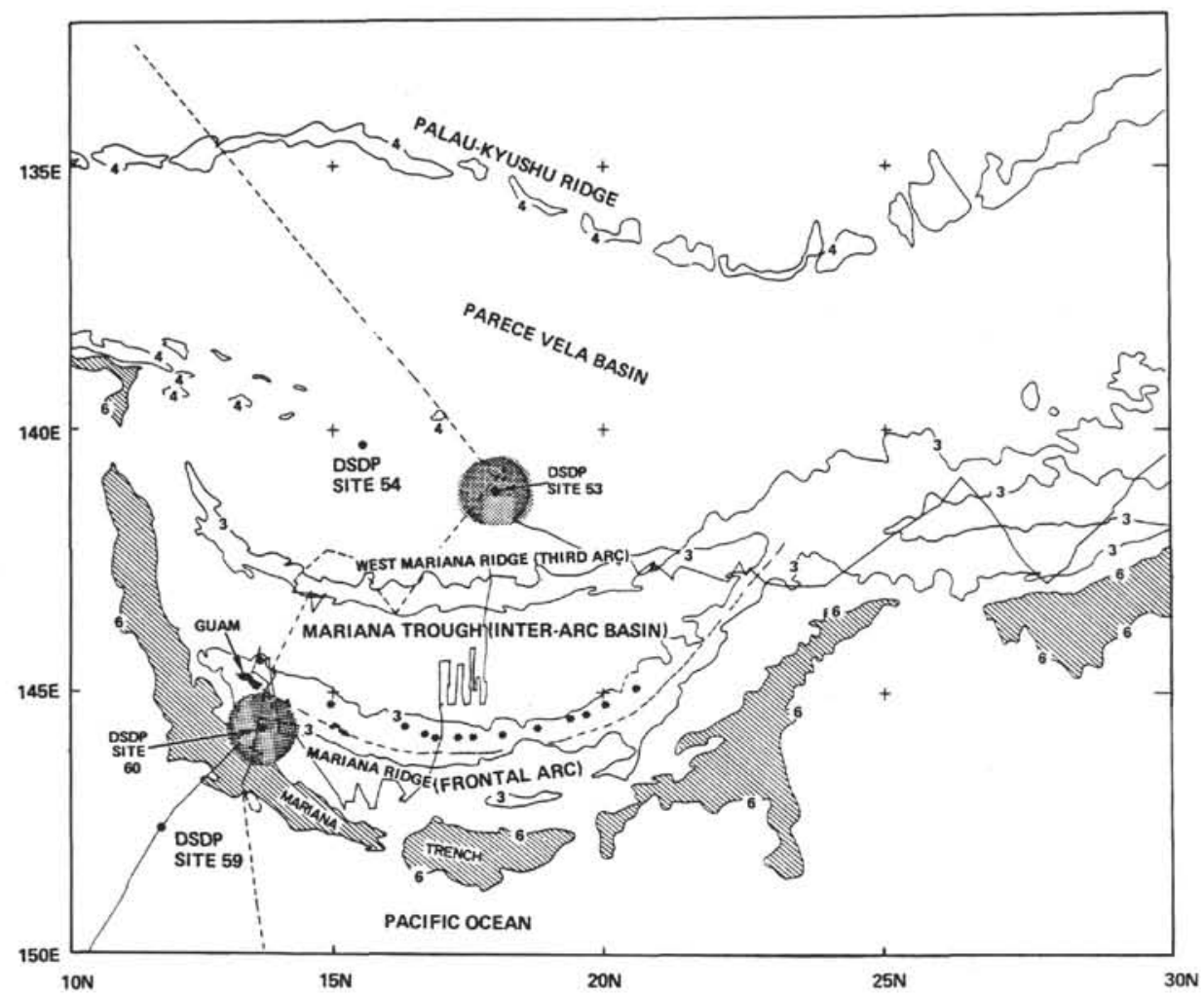

Figure 2. Index map of the eastern Philippine Sea area, with tectonic and geographic features noted and outlined by generalized controus (in kilometers). The frontal arc axis and locations of andesitic volcanoes (asterisks) are also noted. The tracks of $R / V$ Argo on CIRCE (dashed line) and SCAN (solid line) expeditions are shown together with drill sites and survey areas (shaded circles).

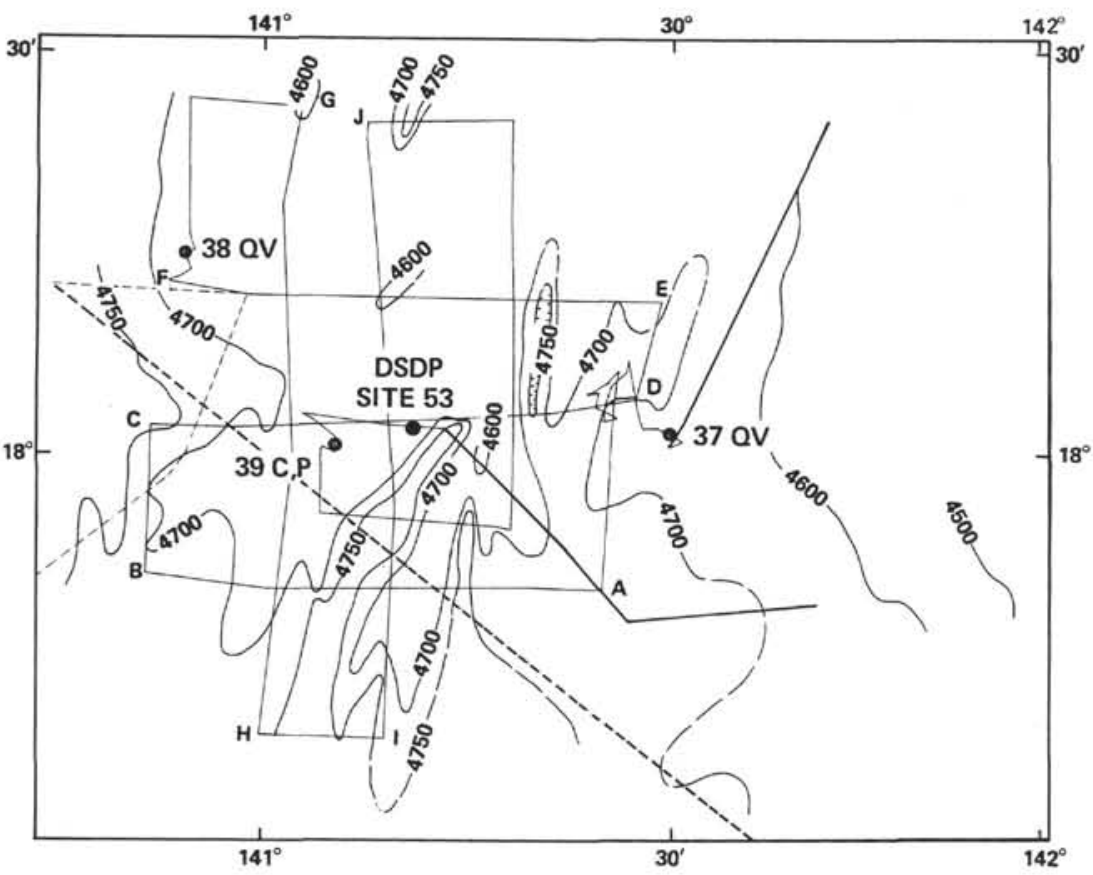

Figure 3. Bathymetry near DSDP Site 53 in meters corrected for sound velocity variation using Matthews tables. $R / V$ Argo tracks on CIRCE (dashed line) and SCAN (solid lines) expeditions are shown with bottom station locations. Station key is camera (C), Piston and gravity (PG), and heat flow $(Q V)$. Positions of seismic profiles in Figure 5 are indicated by numbers. 


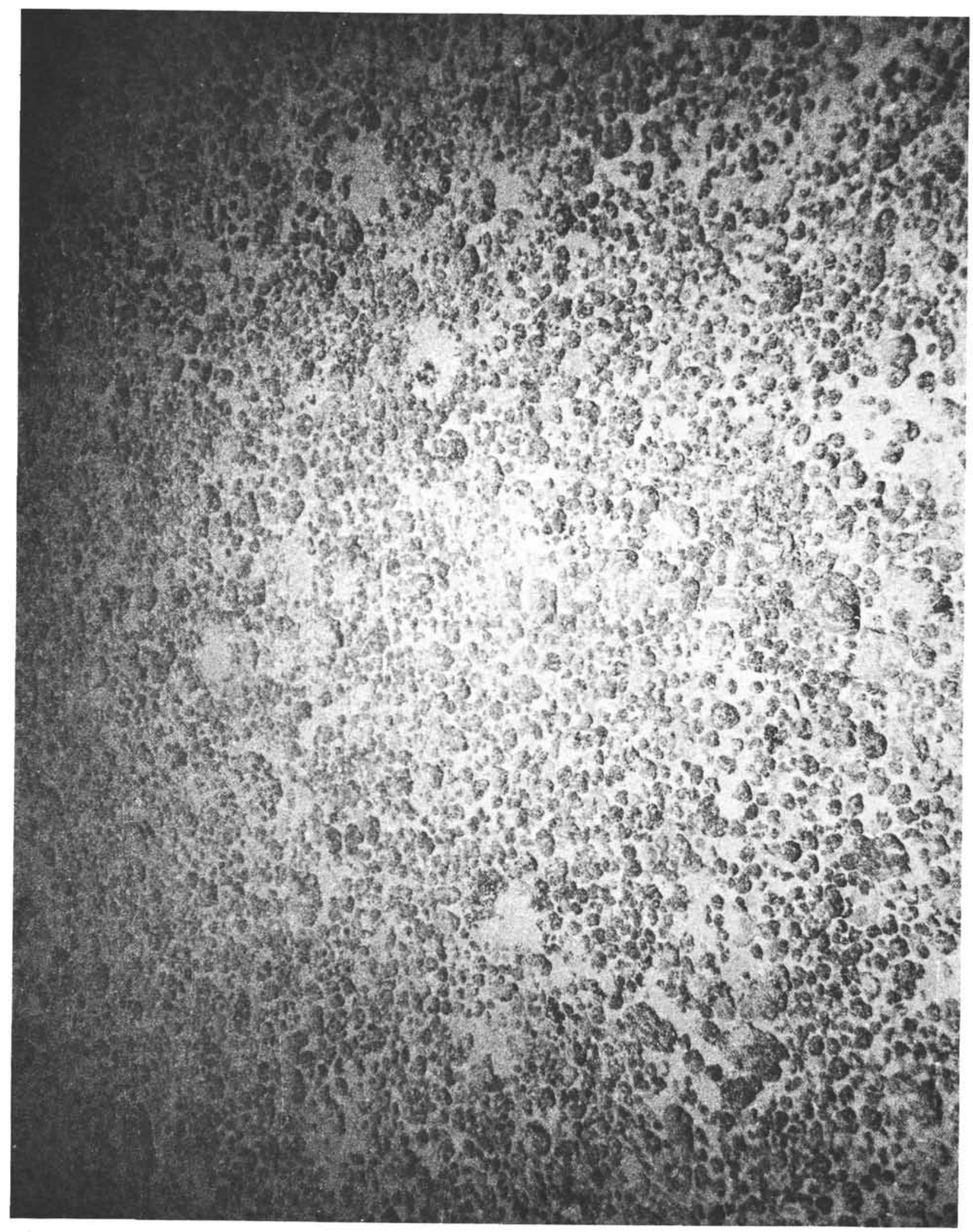

Figure 4. Bottom photograph at station 39C, Site 54. 


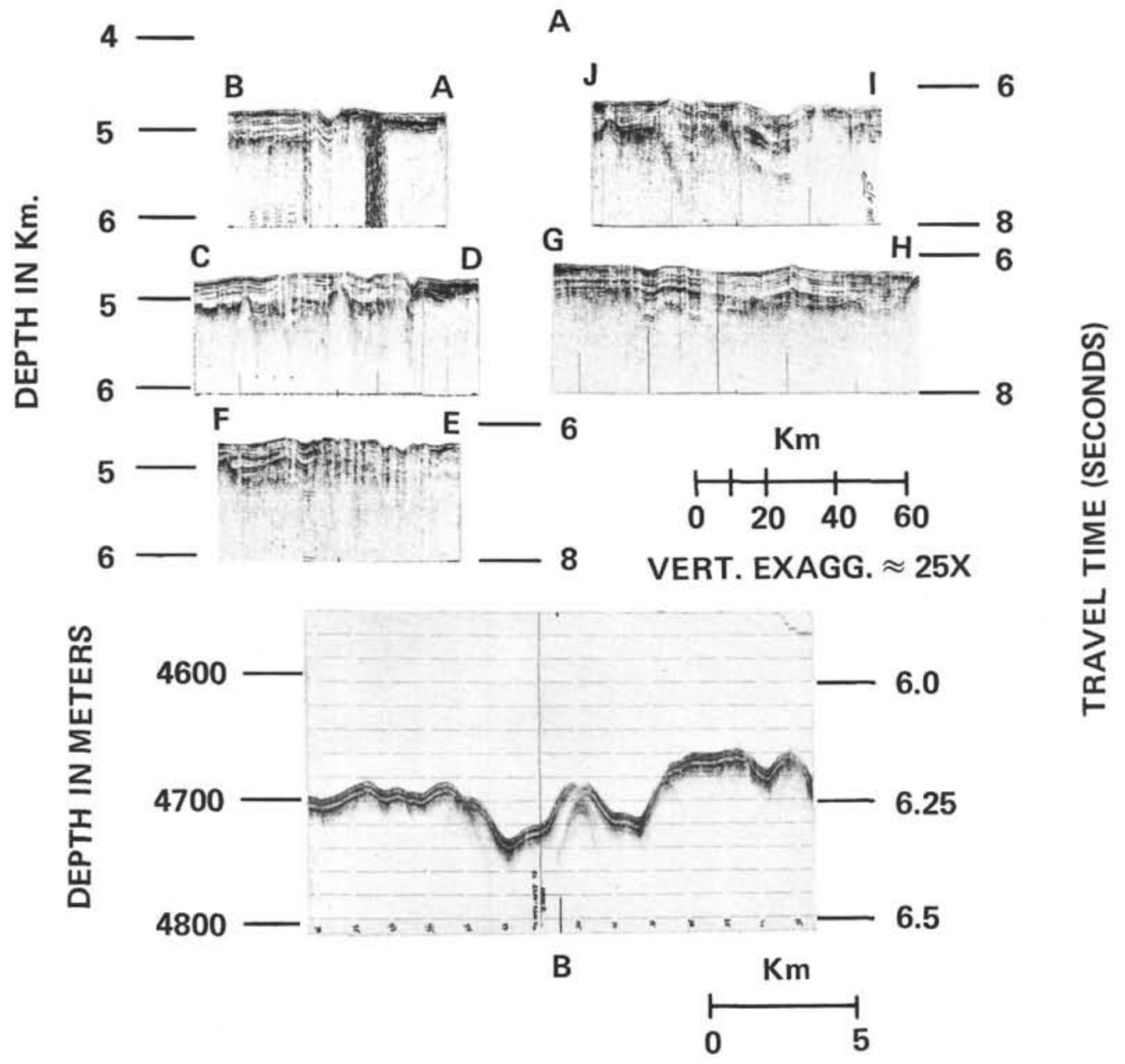

Figure 5. A. Seismic reflection profiles near Site 53. The north-south profiles have a smoother aspect because they parallel the lineation direction.

B. A $3.5 \mathrm{kh}$ record close to Site 53, illustrating the pelagic blanket overlying the apron sediments.

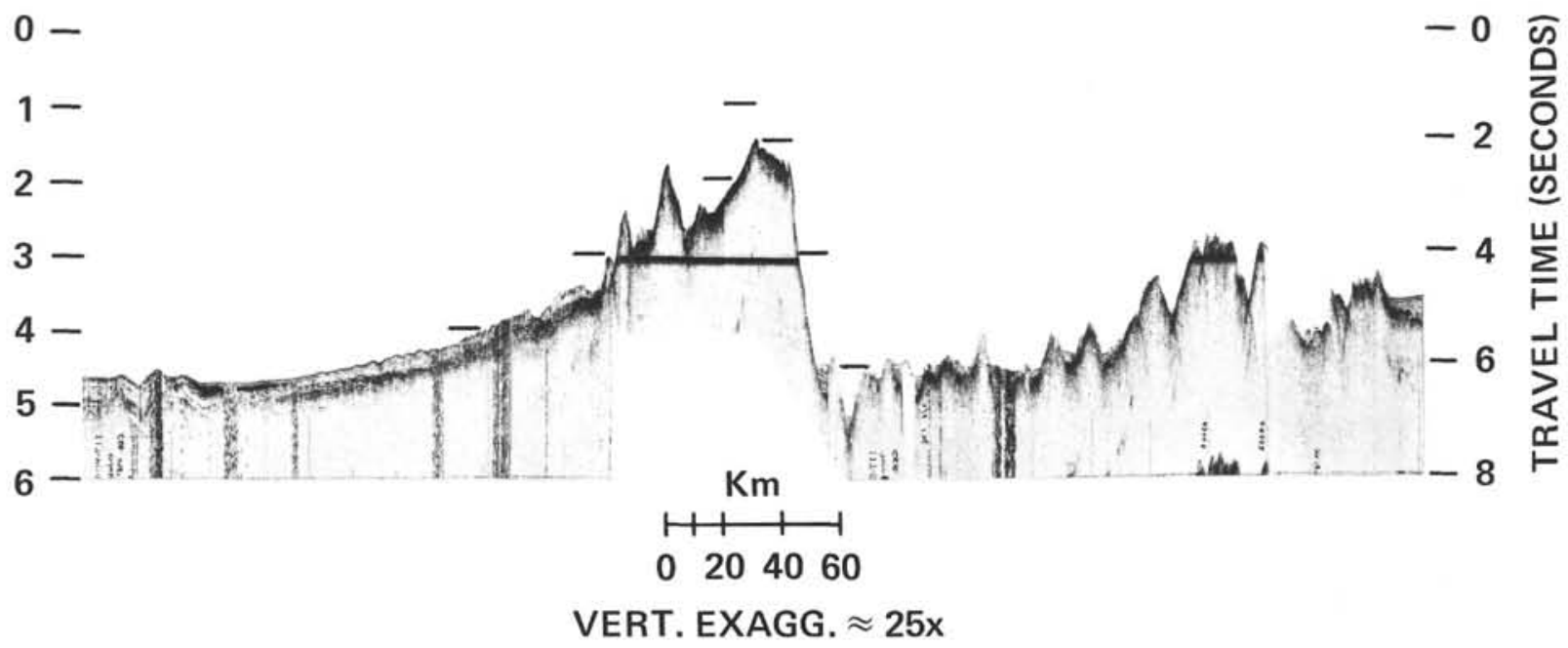

Figure 6. Seismic reflection profile across the West Mariana Ridge and Mariana Trough. Location is shown by the $S C A N$ track on Figure 1 from Site 53 to the first southerly course change at $145^{\circ} 30^{\prime} E$. The sediment pile at the eastern edge of the profile is the toe of the active volcanoclastic apron flanking the volcanic chain. 
apron and several hundred meters in amny of the basement troughs indicate very rapid sedimentation rates within the inter-arc basin.

The eastern flank of the Mariana Trough was crossed between Rota and Guam (Figure 7) where the absence of obscuring andesitic volcanoes reveals the eastern boundary scarp and the strongly asymmetrical crosssection of the Mariana Ridge (frontal arc).

DSDP Site 60 was located at the foot of the sediment apron forming the more gentle upper section of the east flank of the Mariana Ridge (Figures 8 and 9) along the entire Mariana Arc System. The apron is bounded on the east by a ridge or sub-horizontal platform of acoustically opaque material which shallows southward through the site area and, swinging westward toward the frontal arc, causes narrowing and thinning of the sediment apron.

Sediments comprise the apron lap westward onto the steep flank of the basement core of the Mariana Ridge and, although few indications of recent displacement exist along this boundary near Guam, evidence from the analogous feature in the Tonga-Kermadec system suggest that such features are intermittently active normal fault zones (Karig, 1970). Growth of the apron appears to have been made by the overstepping of younger sediments eastward across the basement platform until this platform was completely buried, after which the sediments spilled over onto the lower trench slope (Figure 8).

The apron consists of an alternating sequence of semitransparent and more reflective sediments reaching a thickness in excess of a kilometer (Figure 7). Three sets of these alternations, beginning with a reflective unit at the surface, can be traced throughout the survey area. Toward the source area to the west, these transparent units become more reflective. Because of the overstep of younger sediments, only the upper set and the reflective unit of the second set are observed at Site 60 (Figure 8).

Two piston cores were attempted near the drill site (Scan IV, 52 A and B, Figure 8), but the stiffness of

$0-$

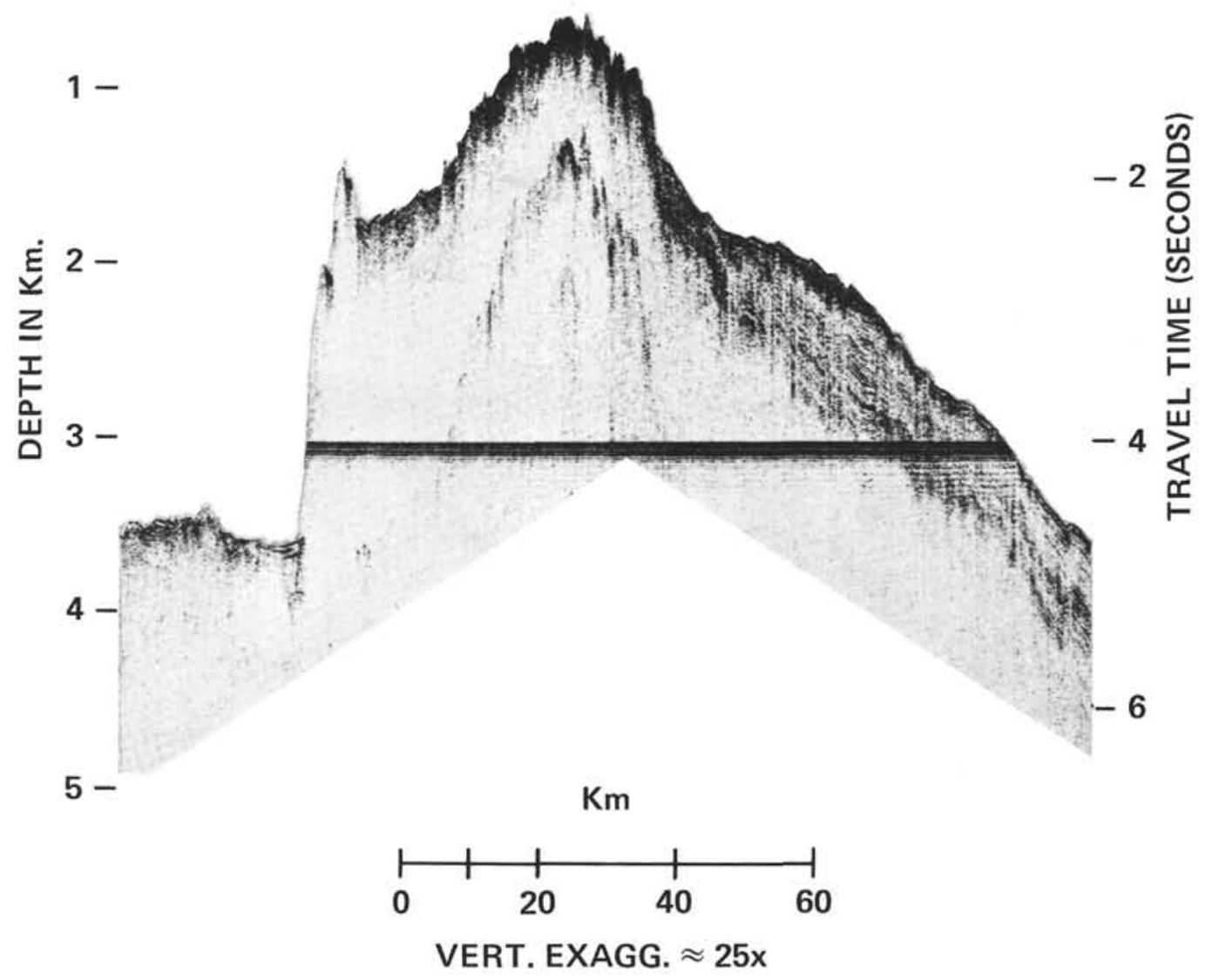

Figure 7. Seismic reflection profile across the Mariana Ridge between Rota and Guam. The ridge asymmetry, with the west flank scarp and the sediment apron on the east are welldeveloped in this area. 


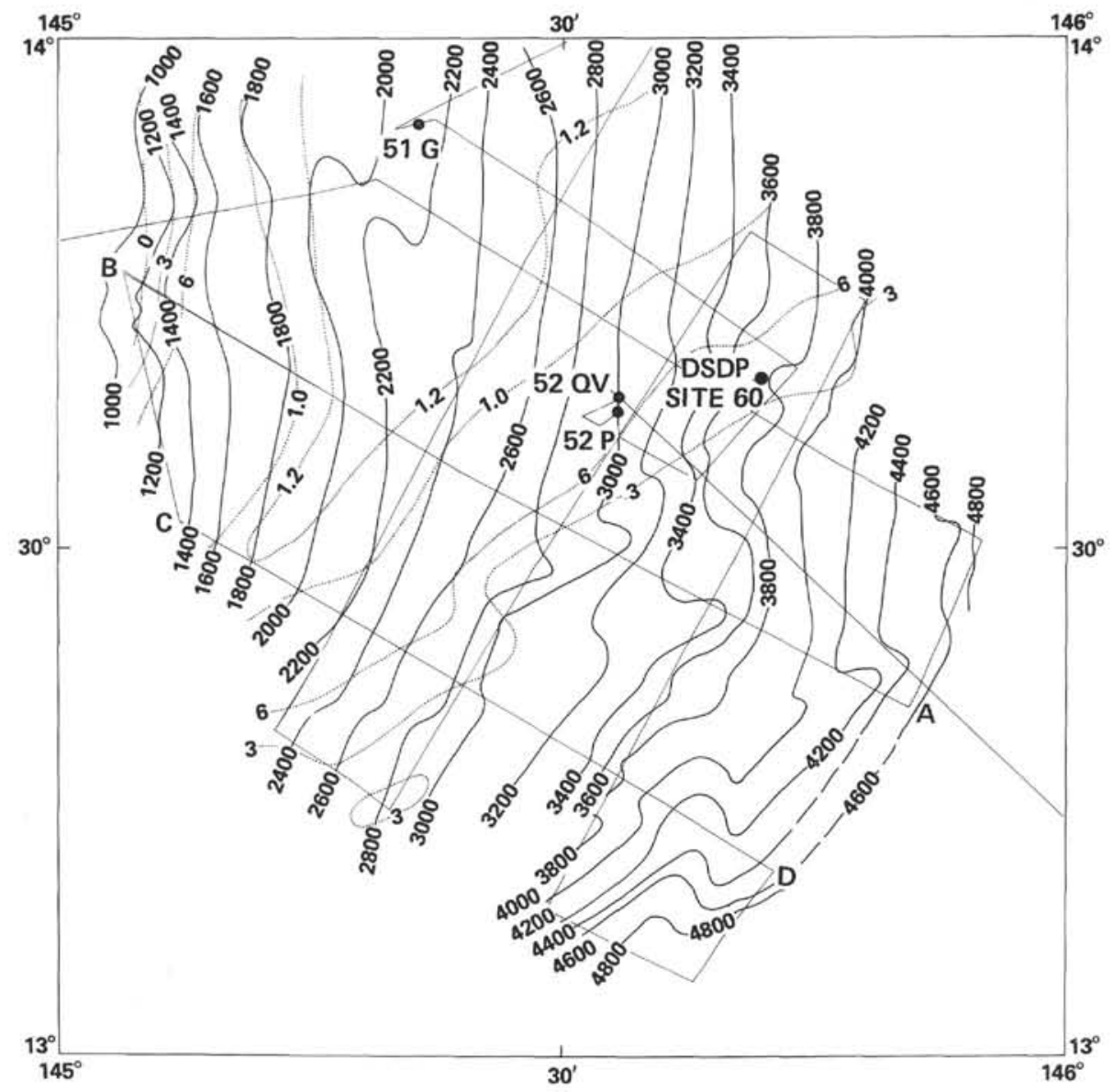

Figure 8. Bathymetry and sediment thickness of the area around DSDP Site 60. Depths are in corrected meters and sediment thicknesses (shown by dotted lines) are in seconds of two-way sound travel time. Tracks, station and drill positions, and profile locations are designated as in Figure 3.

the surficial sediment permitted a core penetration of only two feet, and no core was recovered. In the catcher and smeared on the core barrel was Recent foraminiferal ooze containing admixed Pliocene species (J. C. Ingle, personal communication, 1969). The reworking indicated by foraminifera of mixed ages is thought to result from a downslope transport of sediment by currents and slumping. These processes are suggested by the irregular surface of the apron and the patchy distribution of reflective and transparent surface sediments observed on the $3.5 \mathrm{kh}$ profiles. Sediment redistribution is thought to have contributed to the very low measured heat flow on the apron by reducing the temperature gradient. At DSDP Site 60 the calculated heat flow was negative because the temperature gradient was inverted.

Very little structural deformation of the apron sediments was observed, and consisted only of small displacement normal faults near the head of the apron. Most of these are probably slump features, not involving basement. At the eastern edge of the apron the several basement ridges (marked by 100 to 200 gamma magnetic anomalies) trend sub-parallel to the trench (Figure 9). The lack of deformation in the overlying sediments indicates that these ridges predate at least the younger apron sediments. However, a survey at $15^{\circ} \mathrm{N}$ clearly reveals recent uplift and folding of the outer basement high (Karig, in preparation). The early Tertiary age of this feature in the Bonin Islands suggests a similar age for the Mariana analog. If such an age were correct, the apron sediments should contain much of the Tertiary history of the Mariana Arc System, perhaps delineating periods of tectonic activity and quiescence.

Only the uppermost sediment unit continues east of the basement platform and it disappears as the trench slope steepens below 4500 meters into the trench axis. On the track of the reflection profile connecting DSDP Sites 60 and 59 (Figure 10), the trench was crossed at a depth of 5160 fathoms, where no flat floor nor observable sediments were detected. The eastern, or outer, trench wall contrasts with the western wall in showing a broadly convex upward slope, steeper and 


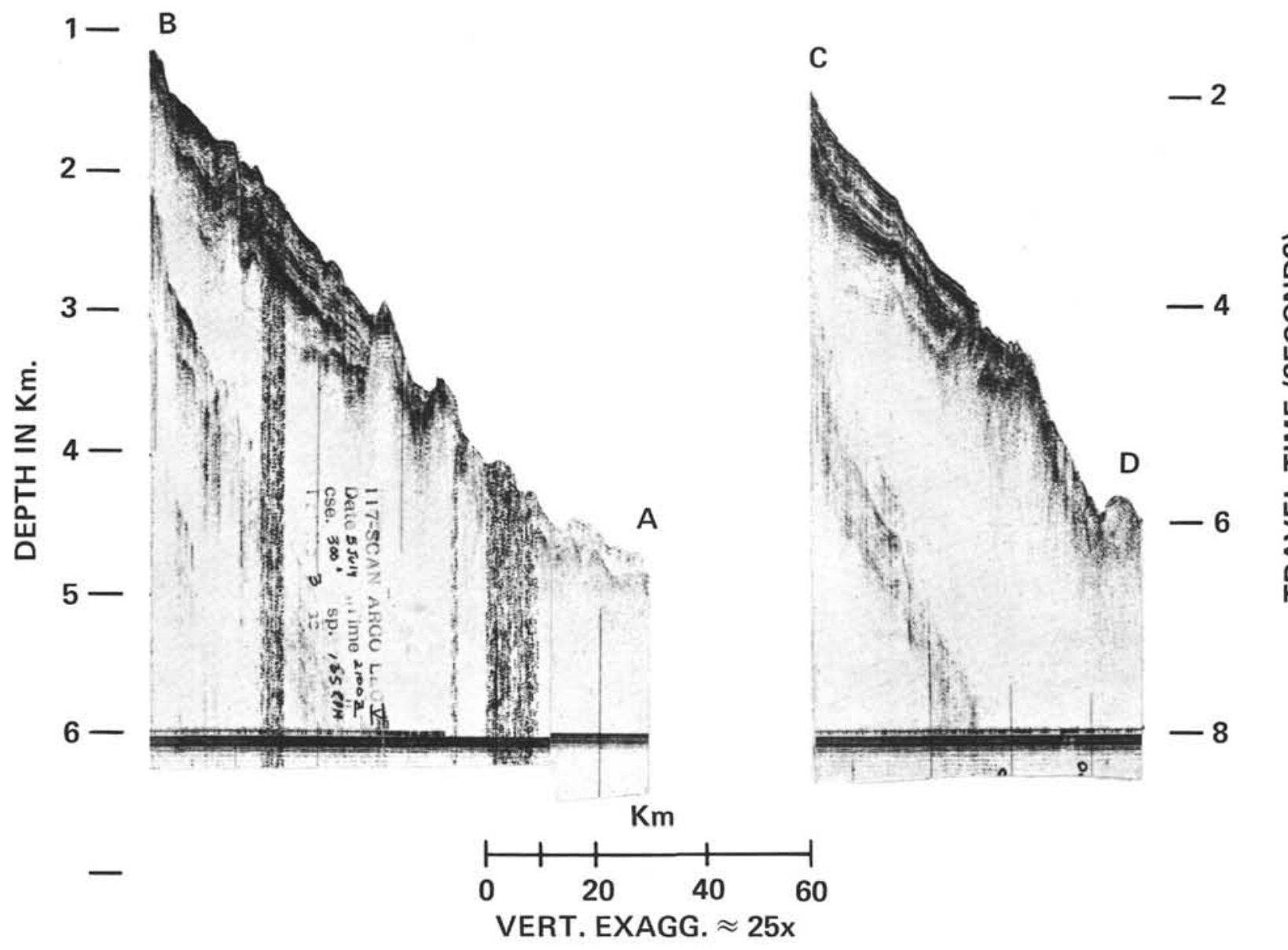

Figure 9. Seismic profiles across the sediment apron drilled by DSDP Hole 60.

and perhaps faulted along the lower section. The convex form continues eastward to form a low swell (Mariana outer ridge) which rises several hundred meters above the general level of the Pacific floor (Mariana Basin). A very thin transparent sediment cover overlies the acoustic basement on the western side of the outer swell but thickens gradually over the crest, eastward toward the Mariana Basin. In the area of the profile, seamounts, up to 1000 meters high, appear to be more abundant on the crest of the outer swell than elsewhere. It is not clear whether these are young features which were formed on a standing wave of crust about to descend into a trench or whether the seamounts are older and their concentration on the swell is merely apparent. The lack of facies change in the transparent sediment surrounding the seamounts suggests that the seamounts are older. Eastward thickening of the transparent section above the opaque basement of the swell continues into the Mariana Basin, accompanied by the appearance of an intermediate reflecting unit (Figure 10).
DSDP Site 59 was located on the western side of the Mariana Basin, east of a small seamount in an area where the thickness of the upper transparent sediment was maximal. At this site, the intermediate reflector was at 0.1 second depth and the acoustic basement at 0.3 second.

The profile east of Site 59 (Figure 10) shows a thinning and virtual disappearance of the transparent layer but a steady thickening of the rest of the section to over 0.5 second. East of $149^{\circ} \mathrm{E}$, the opaque basement traced from the outer ridge is no longer visible because of the increased reflectivity of the shallow sediments. Only a few kilometers further east, the intermediate reflective unit also becomes masked. From this point eastward, across the Mariana Basin, the visible sediment section consists of a single opaque unit at or near the surface. This opaque unit, however, is much younger than the opaque basement of the outer swell, and the responsible lateral acoustic "facies" change is clearly observable. 


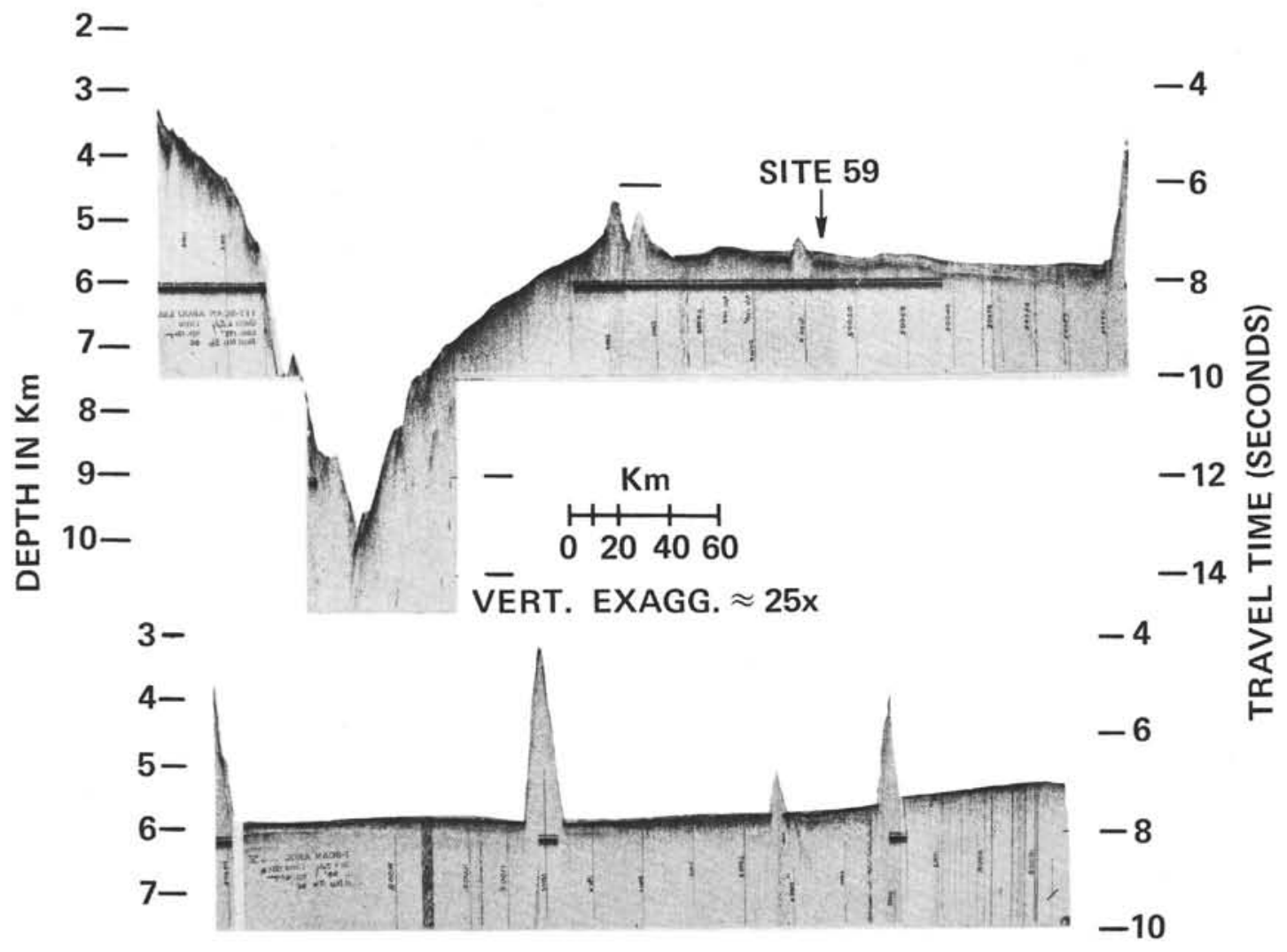

Figure 10. Seismic reflection profile across the Mariana Trench from $13^{\circ} 38^{\prime} \mathrm{N}, 145^{\circ} 33^{\prime} \mathrm{E}$ to $9^{\circ} 42^{\prime} \mathrm{N}$, $151^{\circ} 50^{\prime} E$ (see Figure 1). Location of DSDP Site 59 is shown by arrow.

\section{REFERENCES}

Cloud, P. E., et al., 1956. Geology of Saipan, Mariana Islands. U.S. Geol. Surv. Profess. Paper 280-A. 126 p.

Karig, D. E., 1969. Extensional zones in island arc systems (abst.), Trans. Am. Geophys. Union. 50, 182.

1970. Ridges and basins of the TongaKermadec arc system. J. Geophys. Res. 75, 239.

,(in preparation). Geologic studies in the Mariana island arc system.

Murauchi, S., Den, N., Asano, S., Hotta, H., Yoshii, T., Asaruma, T., Hagiwara, K., Ichikawa, K., Sato, R., Ludwig, W. J., Ewing, J. I., Edgar, N. T. and Houtz, R. E., 1968. Crustal structure of the Philippine Sea. J. Geophys. Res. 73, 3143.
Tracy, J. I., et al., 1964. General Geology of Guam. U.S. Geol. Surv. Profess. Paper 403-A, 104 p.

\section{ACKNOWLEDGMENTS}

The unusual success of SCAN expedition, Legs 4 and 5, was made possible by the supporting scientists, technicians, and crew aboard the $R / V$ Argo. The author remains particularly indebted to J. C. Ingle, of Stanford University, who identified pelagic foraminifera in the SCAN cores during and after the expedition, and to G. G. Shor and Alan Jones, who were responsible for the excellent condition of the shipboard electronics. Comments by B. C. Heezen and A. B. Fischer significantly improved the manuscript. 